\title{
Erratum to: Delayed spontaneous closure of postsurgical cyclodialysis cleft
}

\author{
Osama M. Mustafa · Yassine J. Daoud
}

Published online: 7 June 2017

(C) Springer Science+Business Media Dordrecht 2017

\section{Erratum to: Int Ophthalmol DOI 10.1007/s10792-017-0442-5}

In the original publication, the co-author name was published incorrectly. The correct name should read as Yassine J. Daoud.

The online version of the original article can be found under doi:10.1007/s10792-017-0442-5.

Y. J. Daoud $(\bowtie)$

Cornea, Cataract, and Refractive Surgery Services, Maumenee 327, Wilmer Eye Institute, Johns Hopkins Medical Institutions, 600 North Wolfe Street, Baltimore, MD 21287, USA

e-mail: ydaoud1@jhmi.edu

O. M. Mustafa

College of Medicine, Alfaisal University, Riyadh, Saudi Arabia 